\title{
Internet of Things dan Keberlanjutan Pendekatan Revolusioner Sebaran Petugas Lapangan Pertanian sebagai Enumerator
}

\author{
Internet of Things and Sustainability Approach revolutionary Distribution of Agricultural Field Officers as \\ Enumerators
}

\author{
Maya Dewi Dyah Maharani ${ }^{1 *}$, R Wisnu Prio Pamungkas² \\ ${ }^{1}$ Fakultas Teknik, Program Studi Teknik Lingkungan Universitas Sahid, Jakarta; Jl. Prof. DR. Soepomo No.84, RT.7/RW.1, \\ Menteng Dalam, Kec. Tebet, Kota Jakarta Selatan, Daerah Khusus Ibukota Jakarta 12870 \\ ${ }^{2}$ Fakultas IImu Komputer, Program Studi Informatika Universitas Bhayangkara Jakarta Raya; Jl. Raya Perjuangan-Bekasi \\ Utara, 88955882 \\ *E-mail: maya@usahid.ac.id
}

Diterima: 10 Februari 2021; Disetujui: 17 Agustus 2021

\begin{abstract}
ABSTRAK
Data, informasi real time, serta sebaran Petugas Lapangan (PL) pada urusan pilihan pertanian menjadi salah satu masalah dalam urusan pemerintahan. Hal ini diperlukan Tim Pelaporan yang mengawal data akurat dan jujur melalui statistik pertanian (SP) sebagai bahan baku penyusunan dokumen perencanaan dan evaluasi dalam siklus perumusan strategi. Tujuan penelitian ini adalah memaksimalkan peran PL dalam mengawal data dan informasi SP, melakukan sosialisasi, transformasi dan mengubah cara pandang baik PL Aparatur Sipil Negara (ASN), swasta maupun swadaya tentang pentingnya akurasi data dan informasi yang real time. Penelitian ini menggunakan sumber data primer dan sekunder. Metode perancangan sistem yang digunakan menggunakan metode prototype yaitu: (i) pengumpulan data, (ii) membangun prototype, (iii) evaluasi prototype, (iv) mengkodekan sistem, (v) menguji sistem, (vi) evaluasi sistem, (vii) menggunakan sistem, dan (viii) face validity sistem. Selanjutnya proses System Development Life Cycle (SDLC) diperkuat dengan metode Multidimensional Scaling (MDS), menggunakan software Rap-PL yang merupakan modifikasi dari software RapFish untuk mengetahui indeks keberlanjutan pendekatan revolusioner dalam sebaran PL pertanian. Hasil yang dicapai pada penelitian ini berupa aplikasi monitoring sebaran PL berbasis website dan android pada wilayah kerjanya masing-masing. Pemanfaatan teknologi opensource tak berbayar ini membuat efektifitas, efisiensi, serta meningkatkan kinerja dalam pelaporan PL yang real dan lebih jujur. Penggunaan aplikasi sebaran PL pertanian sebagai pendekatan revolusioner loT dinilai berkelanjutan dengan indeks sebesar 87,57 persen. Kondisi tersebut dapat ditingkatkan, apabila atribut leverage yaitu Para PL berkinerja secara kolaborasi dan berfikir sistemik, sehingga fast respon dapat lebih berkualitas serta dapat mendukung keberhasilan program Jawa Barat Digital Service (JDS) Provinsi Jawa Barat.
\end{abstract}

Kata kunci: data; pelaporan; Petugas-Lapangan; IoT

\section{ABSTRACT}

Data, real-time information, as well as the distribution of Field Officers (FO) agriculture become the problems in government. This requires a Reporting Team that controls accurate and honest data through agricultural statistics. The purpose of this research is to maximize the role of FO (State Civil Apparatus, private as well as self-help) in controlling agricultural statistics data and information. This study used primary and secondary data sources. System design was a prototyping method: (i) data collection, (ii) building prototypes, (iii) evaluation of prototypes, (iv) coding systems, (v) testing systems, (vi) evaluating systems, (vii) using systems, and (viii) system face validity. Furthermore, the System Development Life Cycle (SDLC) process is strengthened by the Multidimensional Scaling (MDS) method, using Rap-FO software which is a modification of RapFish software to determine the sustainability index of revolutionary approaches in agricultural PL distribution. The results achieved in this study are in the form of FO distribution monitoring application based on website and android in their respective working areas. The use of this unpaid open source technology makes effectiveness, efficiency, and improved performance in real and more honest reporting. The use of this applications as a revolutionary approach based on loT is considered sustainable with an index of 87.57 percent. The condition can be improved, if the leverage attributes are the FO perform collaboratively and systemically, so that fast response can be more qualified and can support the success of the West Java Digital Service program in West Java province.

Keywords: data; reporting; Field Officer; IoT

\section{PENDAHULUAN}

Data, informasi real time dan sebaran Petugas Lapangan (PL) Aparatur Sipil Negara (ASN), swadaya dan swasta urusan pilihan pertanian menjadi salah satu masalah dari sekian banyak masalah dalam urusan pilihan pemerintahan di bidang pertanian dan atau pangan. Peran PL pertanian dalam arti luas (tanaman, ternak, ikan) sebagai enumerator dan ujung tombak pengumpulan data statistik yang akurat dan dapat dipertanggungjawabkan sangat penting dan dibutuhkan dalam melaksanakan tugas pokok dan fungsi berdasarkan kompetensinya (Kementerian Pendayagunaan Aparatur Negara dan Reformasi Birokrasi, 2020; 
Kementerian Pertanian, 2014, 2016 dan 2019; Kementerian Kelautan dan Perikanan 2015).

Tugas pokok dan fungsi serta peran $\mathrm{PL}$ dapat ditingkatkan kompetensinya melalui pemanfaatan layanan teknologi Internet of Things (IOT) sebagai keberlanjutan pendekatan revolusioner, agar berkontribusi pada Pembangunan Smart Pertanian. Perkembangan IoT membuat semua objek saling berhubungan dan telah diakui sebagai revolusi teknis. Salah satu aplikasinya adalah dalam sebaran PL pertanian untuk memantau kinerja urusan pilihan pemerintahan di bidang pertanian dan atau pangan. IoT membuat peralatan teknis sistem informasi statistik pertanian lebih efisien dengan memungkinkan pemantauan kinerja Para PL dan para Pejabat setingkat Kepala Sub Bagian Perencanaan dan Evaluasi (Kasubbag Renlap); Kepala Bagian Tata Usaha (Kabag TU) dan Kepala Bidang (Kabid) baik tanaman, peternakan dan perikanan; serta Kepala Dinas (Kadis) secara real time. Uraian Kompetensi dan PL bidang pertanian dapat dilihat pada Tabel 1.

Jumlah Petugas Pertanian Lapangan (PPL) yang dibutuhkan dalam pengawalan dan pendampingan capaian sukses pembangunan sektor pertanian adalah 74 ribu orang PPL. Saat ini baru tersedia 31.500 orang, sehingga masih membutuhkan 42.500 orang (Republika, 2019). Dari jumlah tersebut sebanyak 27.153 orang PPL berstatus ASN, 20.259 orang Tenaga Harian Lepas-Tenaga Bantu (THL-TB) pertanian, dan 16.596 orang PPL swadaya. Sebanyak 13.973 orang dari PPL yang berstatus ASN akan memasuki masa pensiun sampai dengan tahun 2018. Selanjutnya berdasarkan Badan Pengembangan Sumber Daya Manusia, Kementerian Kelautan Perikanan (BPSDM - KKP) jumlah Penyuluh Lapangan Perikanan sebanyak 13.081 orang yang tersebar dari Aceh sampai dengan Papua, dengan rinciannya 3.140 orang berstatus ASN, 96 orang Calon Pegawai Negeri Sipil (CPNS), 1.283 Penyuluh Perikanan Bantu (PPB), 8.522 orang swadaya, dan sebanyak 2.608 orang sangat potensial untuk dijadikan enumerator pengumpulan data statistik perikanan budidaya. Menurut (Kementerian Tenaga Kerja, 2014) jumlah PL Medik Veteriner pada tahun 2015 sebanyak 225 orang dan Paramedik Veteriner sebanyak 546 orang, namun sebaran kedua PL tidak merata.

Tabel 1. Klasifikasi Petugas Lapangan dan Kompetensinya

\begin{tabular}{|c|c|c|}
\hline No & Petugas Lapang & Uraian Kompetensi \\
\hline 1 & Penyuluh Pertanian & Melaksanakan kegiatan teknis di bidang penyuluhan pertanian. \\
\hline 2 & $\begin{array}{l}\text { Pengendali Organisme Pengganggu } \\
\text { Tanaman }\end{array}$ & $\begin{array}{l}\text { Melaksanakan kegiatan teknis di bidang pengendalian Organisme } \\
\text { Pengganggu Tanaman }\end{array}$ \\
\hline 3 & Pengawas Benih Tanaman & Melaksanakan kegiatan teknis di bidang pengawasan benih tanaman \\
\hline 4 & Medik Veteriner & Melaksanakan kegiatan teknis di bidang veteriner \\
\hline 5 & Paramedik Veteriner & $\begin{array}{l}\text { Penyakit Penyakit Hewan Menular Srategis (PHMS) dan PHMS Prioritas, } \\
\text { penyakit zoonosis } \\
\text { Penyakit Rabies, Avian Influenza, Brucellosis, Anthrax, Bovine Spongiform } \\
\text { Encephalopathy (BSE), Salmonella, Kecacingan/parasit, Jembrana, } \\
\text { unggas, ruminansia, TBC, Anthrax } \\
\text { Biosecurity dan biosafety, sanitasi kandang } \\
\text { Produk Hewan, daging asuh, cara memilih produk asuh } \\
\text { Upsus Siwab } \\
\text { Pemeliharaan hewan, istilah pemeriksaan klinis } \\
\text { Pemuliaan ternak } \\
\text { Penyakit Unggas, Ruminansia, Kuda } \\
\text { Higiene dan sanitasi Rumah Potong Hewan, pemotongan, pelayuan } \\
\text { Persyaratan lalu lintas hewan dan produk asal hewan } \\
\text { Inseminasi Buatan, Reproduksi, semen beku, pengobatan, kebuntingan }\end{array}$ \\
\hline 6 & Pengawas Bibit Ternak & Melaksanakan kegiatan teknis di bidang pengawasan perbibitan ternak \\
\hline 7 & Pengawas Mutu Pakan & Melaksanakan kegiatan teknis di bidang pengawasan mutu pakan \\
\hline 8 & Pengawas Mutu Hasil Pertanian & Melaksanakan kegiatan teknis di bidang pengawasan mutu hasil pertanian \\
\hline 9 & Analis Pasar Hasil Pertanian & Melaksanakan kegiatan teknis di bidang analisis hasil pertanian \\
\hline 10 & $\begin{array}{l}\text { Pemeriksa Perlindungan Varietas } \\
\text { Tanaman }\end{array}$ & Melaksanakan kegiatan teknis di bidang perlindungan varietas tanaman \\
\hline 11 & Analis Ketahanan Pangan & Melaksanakan kegiatan teknis di bidang analisis ketahanan pangan \\
\hline 12 & Analis Perkarantinaan Tumbuhan & Melaksanakan kegiatan teknis di bidang analisis perkarantinaan tumbuhan \\
\hline 13 & Pemeriksa karantina Tumbuhan & Melaksanakan kegiatan teknis di bidang pemeriksaan karantina tumbuhan \\
\hline 14 & Dokter Hewan Karantina & Melaksanakan kegiatan teknis di bidang kesehatan hewan \\
\hline 15 & Paramedik Karantina Hewan & Melaksanakan kegiatan teknis di bidang paramedic karantina hewan \\
\hline 16 & Pengawas Alat dan Mesin Pertanian & $\begin{array}{l}\text { Melaksanakan kegiatan teknis di bidang pengawasan alat dan mesin } \\
\text { pertanian }\end{array}$ \\
\hline 17 & Petugas Penyuluh Perikanan & Melaksanakan kegiatan teknis di bidang penyuluhan perikanan \\
\hline
\end{tabular}

Pelaporan PL sangat terkait dengan keberhasilan atau kegagalan program-program pertanian (Arbi, 2017). Program merupakan salah satu komponen dalam dokumen perencanaan dan evaluasi Pembangunan Pertanian. Oleh sebab itu diperlukan peran Tim Pelaporan yang mengawal data dan informasi yang akurat sebagai bahan baku penyusunan dokumen perencanaan dan evaluasi, yang dimulai dari data Statistik Pertanian (SP), Rencana Strategis (RENSTRA), pelaporan (Laporan Kinerja Instansi Pemerintah, Laporan Keterangan Pertanggungjawaban) pada Perangkat Daerah (PD) yang mengatur dan mengarahkan secara teknis urusan pilihan pertanian.

Untuk mendukung program-program Pembangunan Pertanian, diperlukan sebuah sistem yang mendukung monitoring keberlanjutan sebaran PL. Monitoring tersebut berkaitan dengan penggunaan data dan informasi yang bergerak secara dinamis, sehingga monitoring sebaran tidak dapat lagi dilakukan secara konvensional. Perlu adanya sistem pendukung dan dukungan sumber daya yang 
memadai untuk meningkatkan kinerja PL sebagai tindak lanjut sebuah proses kerja yang lebih optimal.

Penyebab lain ketidakakuratan dan kejujuran data dan informasi pertanian adalah kelemahan kompetensi PL di bidang Teknologi Informasi (TI), serta keterbatasan infrastruktur dalam hal penyediaan data sistem monitoring. Sistem berbasis database secara elektronik dapat memudahkan dalam penyediaan data dan informasi yang akurat, pengukuran kinerja, target, relevan, dan tepat waktu untuk digunakan dalam pendataan dan pelaporan PL, serta dalam pengambilan keputusan. Inovasi loT membantu dalam pengumpulan data mengenai situasi yang berkaitan dengan pertanian seperti iklim, kelembaban, curah hujan, kecepatan angin, suhu, kandungan unsur-unsur dalam tanah, pemantauan Organisme Pengganggu Tanaman (OPT), kesehatan hewan dan ikan yang dapat dilakukan oleh Petugas Lapang melalui internet.

Dengan latar belakang masalah tersebut, maka monitoring sebaran PL perlu dibenahi dan dibantu oleh sistem dalam membuat dan mengirimkan pelaporan yang real-time dan update. Sistem Pelaporan berupa sebuah sistem yang menjadi sarana dan prasarana yang sesuai akan kebutuhan pelaporan PL. Penggunaan sistem ini dapat membantu percepatan kinerja PL dengan penggunaan aplikasi berbasis android sebagai pembuatan dan pengiriman data dan informasi. Sedangkan untuk monitor sebaran PL akan didukung oleh aplikasi berbasis website berbasis sistem informasi geografis (Balakrishna \& Mopathi, 2019) dalam rangka monitoring dan evaluasi aktifitas yang dilakukan oleh PL. Dengan adanya aplikasi ini diharapkan semua pihak terkait bisa secara menyeluruh mendapatkan laporan hasil kinerja PL yang update dan real time secara terukur, efisien dan efektif, sehingga mendukung pengambilan suatu keputusan yang bijaksana.

Pemanfaatan layanan teknologi IoT pada awalnya dihadapkan pada kekuatan disruptif (Prapitasari, Sumiari, \& Jayanti, 2016). Namun secara perlahan IoT adalah salah satu pilihan pendekatan revolusioner untuk berbagai bidang, termasuk pertanian. Berdasarkan permasalahan tersebut, maka tujuan penelitian ini adalah memaksimalkan peran PL dalam mengawal data dan informasi statistik pertanian, melakukan sosialisasi dan mengubah cara pandang baik PL ASN, swasta, dan swadaya tentang pentingnya akurasi data dan informasi yang real time serta akurat.

\section{METODOLOGI}

Metode penelitian yang diterapkan adalah metode System Development Life Cycle (SDLC), yaitu dalam bentuk prototype yaitu dengan tahapan-tahapan kerja yang bertujuan untuk menghasilkan sistem berkualitas tinggi yang sesuai dengan kebutuhan user atau tujuan dibuatnya sistem tersebut. Tahapan-tahapan tersebut meliputi: (i) Pengumpulan data, (ii) membangun prototype, (iii) evaluasi prototype, (iv) mengkodekan sistem, (v) menguji sistem, (vi) evaluasi sistem, (vii) menggunakan sistem (Muhammad Suryanegara, et. al., 2019; Mulyanto, 2009), dan face validity kepada Para Pengambil Keputusan baik di tingkat direktif, strategis, operasional dan teknis.

Siklus Hidup Pengembangan Sistem atau SDLC, dalam rekayasa sistem dan rekayasa perangkat lunak, adalah proses pembuatan dan pengubahan sistem serta model dan metodologi yang digunakan untuk mengembangkan sistemsistem. Konsep ini umumnya merujuk pada sistem komputer atau informasi (Bagus, Ari \& Heranurweni, 2019). Metode project life cycle dalam bentuk prototype sudah banyak diterapkan di bidang pertanian dan lainnya (BINUS University, 2020; Joao \& Hugo, 2018).
Dalam proses tahapan pengumpulan data merupakan langkah nyata pendekatan revolusioner dalam pemanfaatan IOT sebagai paradigma baru untuk mengubah kebutuhan hidup berteknologi tinggi (Sachin, Prayag \& Mikhail, 2019). Namun demikian berbagai tantangan dan masalah dalam pemanfaatan IoT (seperti aplikasi sebaran PL), teknologi, dampak sosial dan lingkungan. Tahapan membangun prototype, merupakan tahapan yang berfokus pada penyajian pelanggan. Misalkan membuat input dan output hasil system (Muhammad Suryanegara, et. al., 2019). Aktifitas ini menghasilkan spesifikasi fungsional. Tahapan ini memerlukan evaluasi untuk mengetahui kemampuan sistem dengan mendefinisikan apa yang seharusnya dapat dilakukan oleh sistem tersebut kemudian menentukan kriteria yang harus dipenuhi sistem. Beberapa kriteria yang harus dipenuhi adalah pencapaian tujuan, kecepatan, biaya, kualitas informasi yang dihasilkan, efisiensi dan produktivitas, ketelitian dan validitas dan keandalan atau reliabilitas (Pannee \& Pitchaya, 2019)

Selanjutnya proses metode $S D L C$ diperkuat dengan metode Multidimensional Scaling (MDS), menggunakan software Rap-PL yang merupakan modifikasi dari software RapFish untuk mengetahui indeks keberlanjutan pendekatan revolusioner dalam sebaran $\mathrm{PL}$ pertanian. MDS pada hakekatnya adalah perceptual mapping (pemetaan persepsi) yang mengandalkan Euclidean Distance (ED) antara satu dimensi dengan dimensi yang lain. Dalam MDS atribut atau ukuran yang akan diukur dapat dipetakan dalam $E D$ dimana benda yang dipersepsikan memiliki karakteristik yang sama dianggap memiliki $E D$ terdekat. Sebaliknya objek dengan karakteristik yang berbeda disebut memiliki dissimilarities sehingga perbedaan keduanya dapat diukur dalam jarak persepsi yang diterjemahkan dalam indeks persepsi seperti indeks keberlanjutan. Teknik penentuan jarak didasarkan pada $E D$ dengan formula sebagai berikut:

$d_{1,2}=\sqrt{\left(X_{1}-X_{2}\right)^{2}+\left(Y_{1}-Y_{2}\right)^{2}+\left(Z_{1}-Z_{2}\right)^{2}+\cdots}$

Keterangan:

$\mathrm{d}_{1,2} \quad=$ Jarak euclidian

$\mathrm{X}, \mathrm{Y}, \mathrm{Z}=$ Atribut

$1,2=$ Pengamatan

Jarak $E D$ antara dua titik tersebut $\left(\mathrm{d}_{1,2}\right)$ kemudian di dalam $M D S$ diproyeksikan ke dalam jarak $E D$ dua dimensi $\left(d_{1,2}\right)$ berdasarkan rumus regresi pada persamaan berikut:

$d_{1,2}=a+b d_{1,2}+c$

Keterangan:

$\mathrm{a}=$ intercept

$\mathrm{b}=$ slope

$\mathrm{c}=$ error

Dalam MDS, dua titik atau obyek yang sama dipetakan dalam satu titik yang saling berdekatan. Teknik yang digunakan adalah algoritma ALSCAL dan mudah tersedia pada hampir setiap software statistik (SPSS dan SAS). Rap$\mathrm{PL}$ pada prinsipnya membuat iterasi proses regresi tersebut sedemikian sehingga didapatkan nilai e yang terkecil dan berusaha memaksa agar intercept pada persamaan tersebut sama dengan $0(\mathrm{a}=0)$. Iterasi berhenti jika stress $<0,25$. Melalui metode rotasi, maka posisi titik keberlanjutan dapat divisualisasikan melalui sumbu horizontal dan vertikal dengan nilai indeks keberlanjutan diberi skor 0 persen (buruk) dan 100 persen (baik). Jika sistem yang dikaji mempunyai nilai indeks keberlanjutan lebih besar atau sama dengan 50 persen, maka sistem dikatakan berkelanjutan (sustainable), dan tidak berkelanjutan jika nilai indeks kurang dari 50 persen. Ilustrasi penentuan indeks keberlanjutan 
dalam skala ordinasi pada dua titik ekstrim buruk (0 persen) dan baik (100 persen). Dari hasil analisis tersebut diperoleh pengaruh galat yang dapat disebabkan oleh berbagai hal seperti kesalahan dalam pembuatan skor, kesalahan pemahaman terhadap atribut atau kondisi lokasi penelitian yang belum sempurna, variasi skor akibat perbedaan opini atau penilaian oleh peneliti, proses analisis MDS yang berulang-ulang, kesalahan input data atau ada data yang hilang dan tingginya nilai stress.

$$
\text { stress }=\sqrt{\frac{1}{m} \sum_{k=1}^{m}\left(\begin{array}{llll}
\sum_{i} & \sum_{j} & \left(D_{i j k}^{2}-d_{i j k}^{2}\right)^{2} \\
\hline \sum_{i} & \sum_{j} & d_{i j k}^{2}
\end{array}\right)}
$$

\section{Keterangan:}

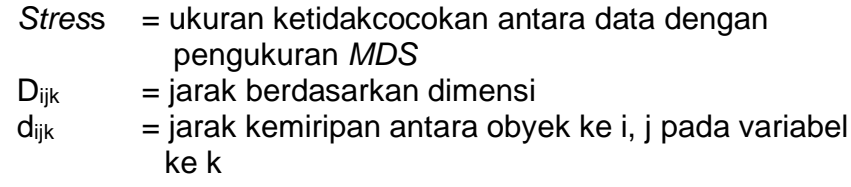

Analisis leverage untuk mengetahui efek stabilitas jika salah satu atribut dihilangkan saat dilakukan ordinasi. Hasil analisis Leverage menunjukkan persen perubahan root mean square (RMS) masing-masing atribut. Atribut yang memiliki persentase tertinggi merupakan atribut paling sensitif terhadap keberlanjutan

Untuk mengevaluasi pengaruh galat pada pendugaan nilai ordinasi digunakan analisis Monte Carlo, yaitu metode simulasi statistik untuk mengevaluasi efek dari random error pada proses pendugaan, serta untuk mengevaluasi nilai yang sebenarnya

Output dari analisis Rap_PL adalah indeks keberlanjutan dari 0-100 yang ditampilkan dalam indikator ordinasi dan leveraging. Indeks keberlanjutan dikelompokkan dalam 4 kategori yaitu: (i) 0-25 (buruk atau tidak berkelanjutan); (ii) 25,01-50 (kurang berkelanjutan); (iii) 50,01-75 (cukup berkelanjutan); (iv) 75,01-100 (baik atau sangat berkelanjutan).

\section{HASIL DAN PEMBAHASAN}

Pengembangan aplikasi akan dilakukan dengan versi web dan android, sehingga perlu digali kebutuhan user. Aplikasi berbasis web akan digunakan oleh user yang mempunyai jabatan Kasubbag Renlap sebagai Pengawas Lapangan yang bertanggungjawab terhadap data dan informasi di lapang. Selanjutnya Kabag TU sebagai atasan Kasubbag Renlap, juga Kabid (Tanaman, Peternakan, Perikanan) sebagai Supervisor, dan Kadis (Tanaman, Peternakan, Perikanan, Ketahanan Pangan) sebagai Manajer.

Bagi Kadis sebagai Manajer, aplikasi berbasis web diantaranya berperan untuk: (i) memberikan dan melihat validasi aktivitas harian, dan fast response yang dilakukan oleh PL yang telah divalidasi oleh Kabag TU, Para Kabid, dan Kasubbag Renlap; (ii) melihat sebaran PL dengan memanfaatkan koordinat Global Positioning System (GPS) pada handphone saat pengambilan gambar di lapangan (Gambar 1).

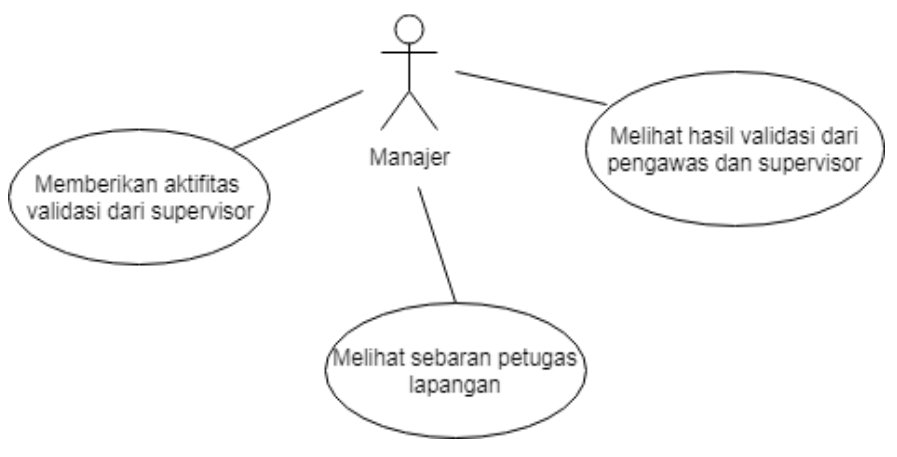

Gambar 1. Use Case Kepala Dinas sebagai Manajer

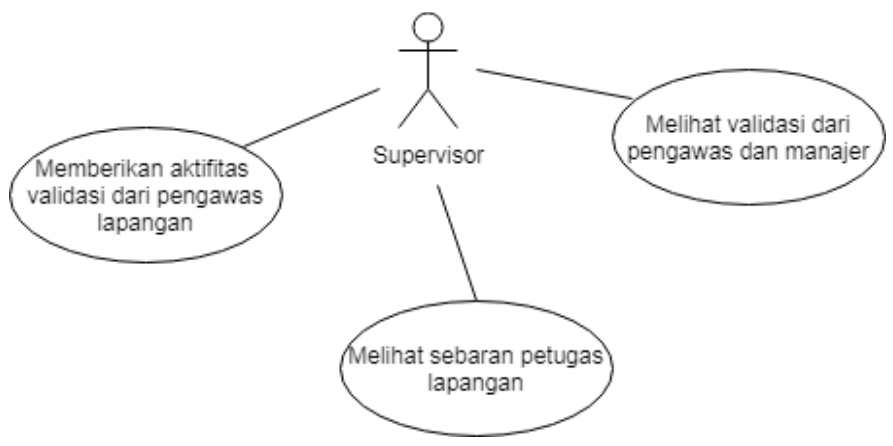

Gambar 2. Use Case Kabag TU dan Kabid sebagai Supervisor

Bagi Kabag TU dan Para Kabid sebagai Supervisor, aplikasi berbasis web diantaranya berperan untuk: (i) memberikan dan melihat validasi aktivitas harian, serta fast response PL yang telah divalidasi oleh Kasubbag Renlap, dan dikirim ke Kabag TU dan Para Kabid (Tanaman, Ternak, Perikanan); (ii) melihat hasil validasi Kasubbag Renlap atas aktifitas harian PL; (iii) melihat sebaran $\mathrm{PL}$ dengan memanfaatkan koordinat GPS pada handphone saat pengambilan gambar di lapangan.

Bagi Kasubbag Renlap sebagai Pengawas Lapangan, aplikasi berbasis web diantaranya berperan untuk: (i) memberikan aktifitas harian dan fast response kepada PL;

(ii) melakukan monitoring daftar hadir, aktivitas harian; dan

(iii) melakukan validasi aktifitas harian, aktivitas lain, dan 
aktivitas fast response PL, untuk selanjutnya dikirim ke Kabag TU dan Para Kabid sebagai atasan langsung.

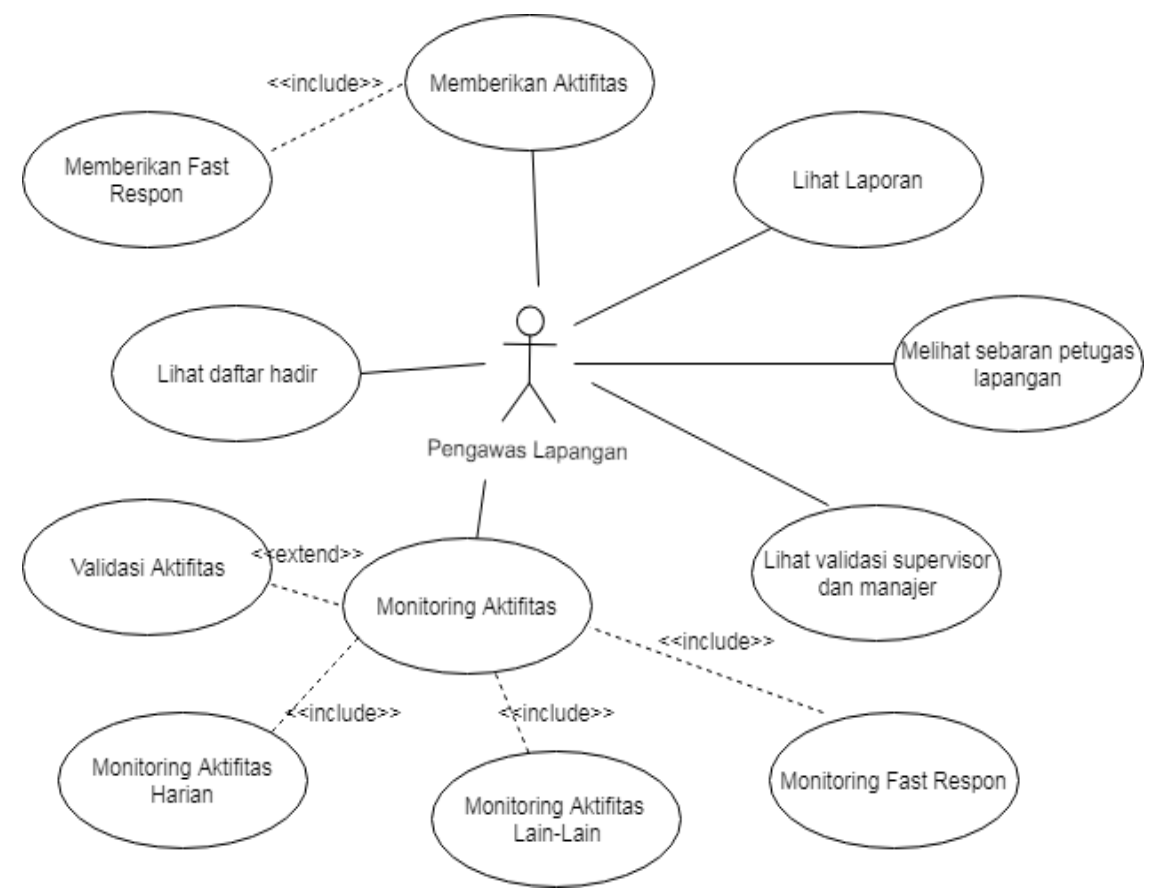

Gambar 3. Use Case Ka-Sub Bag RenLap sebagai Pengawas Lapangan

Bagi Admin user, aplikasi berbasis web ini akan digunakan oleh berbagai tingkatan user yang diatur oleh admin user, yang berfungsi: (i) update PL sesuai jabatannya; (ii) update user ke dalam pengelompokan jenis user (Admin, Kasubbag Renlap, Kabag TU, dan Para Kabid, serta Kadis); (iii) update Jabatan; serta aktivitas sesuai jabatan.

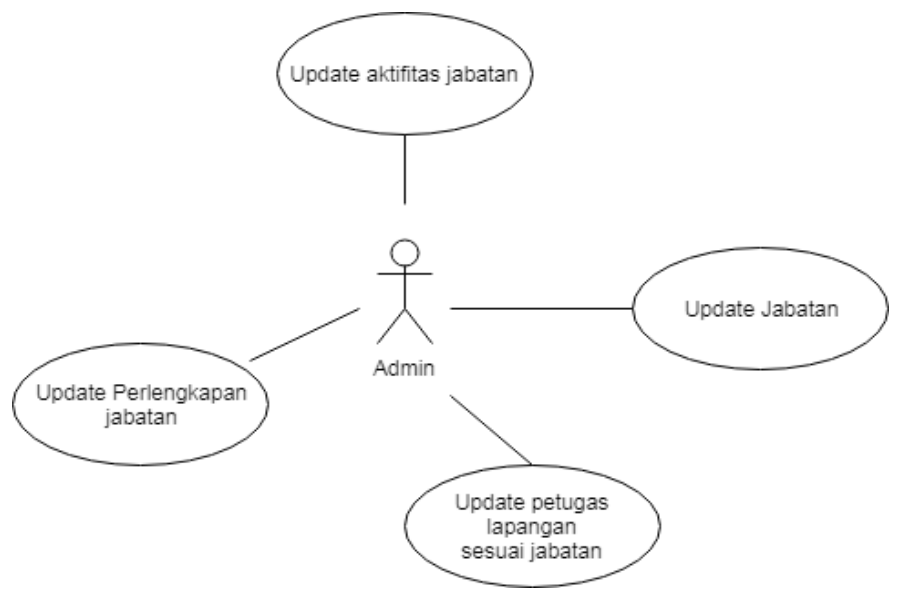

Gambar 4. Use Case Admin 


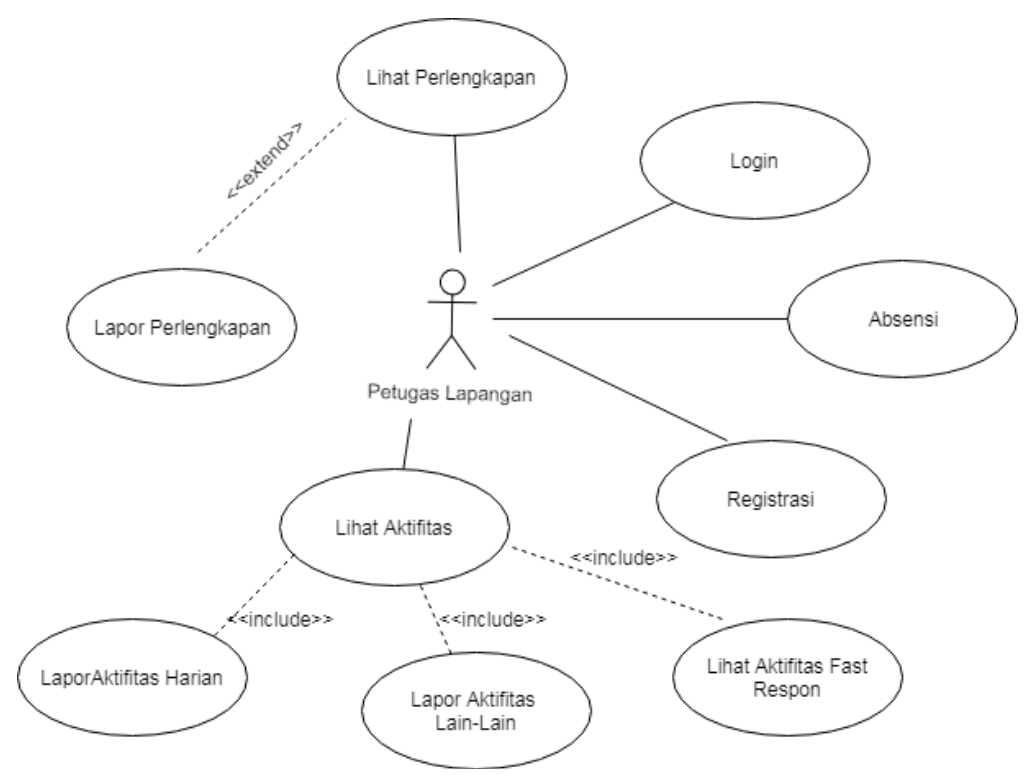

Gambar 5. Use Case Petugas Lapangan

Aplikasi berbasis android akan digunakan oleh PL untuk hal-hal berikut: (i) registrasi penggunaan aplikasi android dan membuat password user; (ii) melakukan aktifitas harian sesuai tugas pokoknya; dan fast response harian yang diperoleh dari Kasubbag Renlap; (iv) melakukan aktifitas lain-lain yang diperoleh secara lisan dari Kasubbag Renlap, atau inisiatif di lapangan; serta (v) melihat history dari aktifitas yang aktif-sedang proses-sudah selesai.

Desain database dibuat untuk menyiapkan dasar kebutuhan database yang akan digunakan untuk persiapan aplikasi yang dibutuhkan dalam proses penyimpanan dan transaksi data. Dalam komunikasi database antar aplikasi yang dibutuhkan sebagai bentuk web service, Application Programming Interface ( $A P I)$ akan menyebutkan data-data apa saja yang akan dibutuhkan dari database aplikasi android dengan database aplikasi laporan website.
Aplikasi yang dibangun adalah sistem terintegrasi antara web laporan, android laporan dan database terpusat, sehingga aplikasi dapat digunakan untuk kebutuhan lain atau aplikasi lain dengan memanfaatkan data. Pemanfaatan data dapat berupa koordinat data pada foto yang digunakan sebagai data lokasi atau peta dari pengguna. Untuk desain dengan Unified Modelling Language (UML) jenis Use Case. Aplikasi website terdiri dari user pengawas lapangan, supervisor dan manajer serta Admin / Super User, demikian juga aplikasi Android terdiri dari kegiatan-kegiatan yang dilaksanakan oleh seorang PL (Gambar 5).

Selanjutnya komponen-komponen dari arsitektur topologi meliputi: (i) Web Service; (ii) Web Application, (iii) Koordinat GPS; (iv) Database; dan (v) Android Aplikasi dapat dilihat pada Gambar 6.
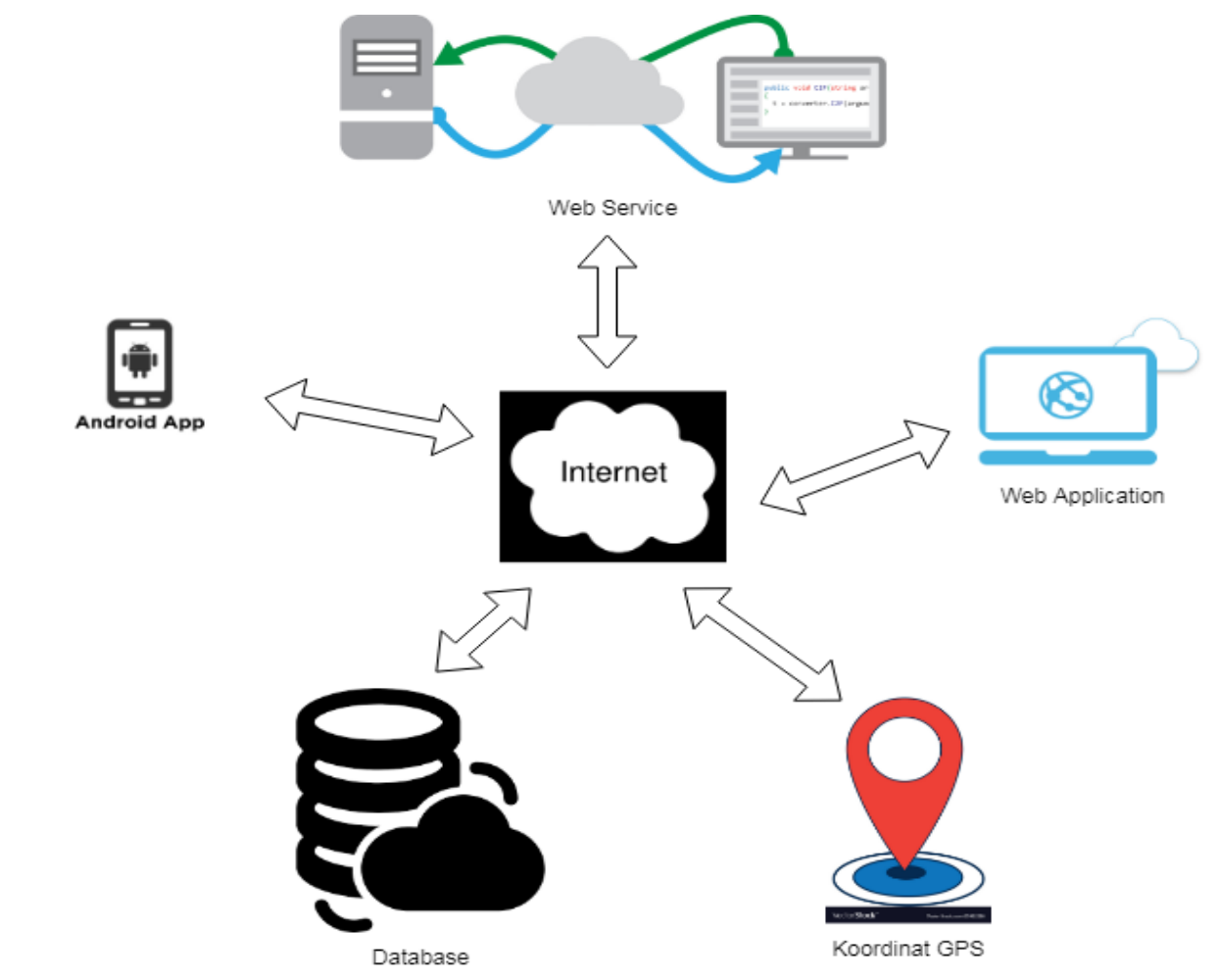

Gambar 6. Arsitektur Topologi 
Gambar 6, menunjukkan bahwa arsitektur topologi sistem dibangun oleh beberapa komponen yang saling terkait. Komponen Aplikasi Web, adalah aplikasi yang dibangun untuk pengguna yang berfungsi sebagai validasi semua kegiatan-kegiatan dari PL Pertanian. Aplikasi Web dapat diakses oleh Kadis, Kabag TU, Para Kabid, serta Kasubbag Renlap. Selain itu, Aplikasi Web dapat digunakan untuk melihat atau memonitor aktifitas dari PL Pertanian dan yang terpenting adalah melihat posisi sebaran PL Pertanian. Komponen Aplikasi Android, adalah aplikasi yang dibangun untuk proses aktivitas PL Pertanian sesuai dengan tugas pokok dan fungsi masing-masing sesuai klasifikasi PL Pertanian. Komponen Aplikasi Android dapat mengakomodasi kebutuhan kehadiran atau kegiatan- kegiatan dari PL Pertanian, sehingga PL Pertanian dapat mengerjakan tugas dan fungsinya yang diberikan oleh Kasubbag Renlap terhadap dirinya.

Komponen database, merupakan lokasi data yang akan digunakan sebagai penyimpanan data maupun penggunaan data transaksi aplikasi. Sedangkan komponen Koordinat GPS, adalah spesifikasi fungsional yang diimplementasikan melalui geotag handphone saat pengambilan foto sebagai laporan aktivitas petugas lapangan.

Untuk menguji pemanfaatan $I O T$ dilakukan dengan skenario menggunakan metode blackbox melalui prosedur Alpha Test menjadi perlakuan uji coba yang disesuaikan secara role atau aturan Business Process dari aplikasi.

Tabel 2. Uji Sistem Metode Blackbox

\begin{tabular}{|c|c|c|c|c|}
\hline No & Jenis Aplikasi & Test Case & Hasil yang diharapkan & Keterangan \\
\hline 1 & \multirow{3}{*}{ Website } & Pengujian halaman login & $\begin{array}{l}\text { Sistem akan memproses form apabila username } \\
\text { dan password yang diisi adalah benar }\end{array}$ & Berhasil \\
\hline 2 & & $\begin{array}{l}\text { Pengujian halaman monitor } \\
\text { kehadiran PL Pertanian }\end{array}$ & $\begin{array}{l}\text { Sistem menampilkan data dari tabel kehadiran } \\
\text { yang telah diisi melalui perangkat android PL } \\
\text { Pertanian }\end{array}$ & Berhasil \\
\hline 3 & & $\begin{array}{l}\text { Pengujian halaman monitor } \\
\text { sebaran posisi PL } \\
\text { Pertanian }\end{array}$ & $\begin{array}{l}\text { Sistem menampilkan peta wilayah binaan PL } \\
\text { Pertanian dan terdapat data koordinat dari foto } \\
\text { laporan yang dibuat PL Pertanian }\end{array}$ & Berhasil \\
\hline 4 & \multirow[b]{2}{*}{ Android } & Pengujian halaman login & $\begin{array}{l}\text { Sistem akan memproses form apabila username } \\
\text { dan password yang diisi adalah benar }\end{array}$ & Berhasil \\
\hline 5 & & Pengujian halaman utama & $\begin{array}{l}\text { PL Pertanian dapat mengakses semua fungsi pada } \\
\text { menu utama apabila ingin bekerja membuat } \\
\text { laporan }\end{array}$ & Berhasil \\
\hline
\end{tabular}

Beberapa kegiatan yang dilakukan oleh PL Penyuluh Pertanian, Paramedik Veteriner, Penyuluh Perikanan dapat dilihat pada Gambar 7, 8, 9, sedangkan Gambar 10 adalah data absensi Petugas Lapangan Pertanian.

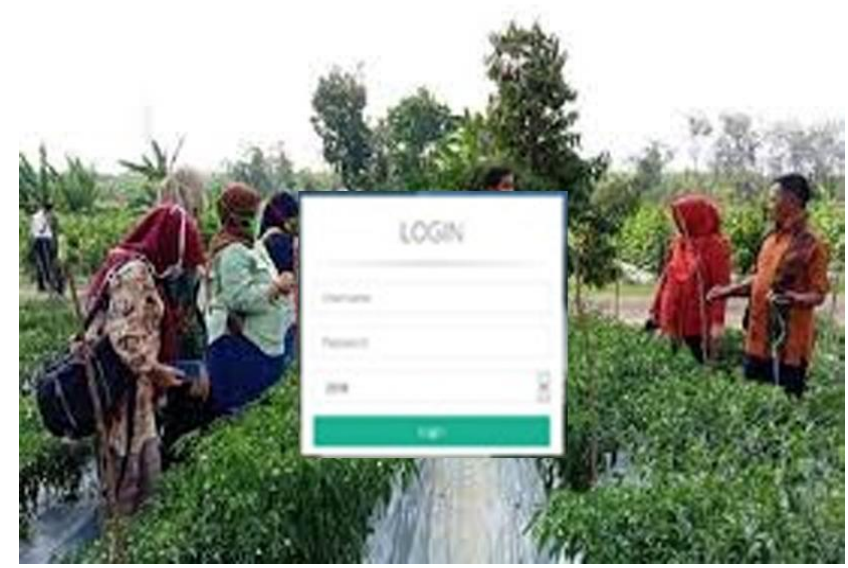

Gambar 7. Halaman Login Aplikasi Web

Halaman login ini, dibuat dengan bentuk pilihan jenis user. Ada beberapa pilihan yaitu: (i) Admin; (ii) Kadis sebagai Manajer; (iii) Kabag TU dan Para Kabid sebagai Supervisor; serta (iii) Kasubbag RenLap sebagai Pengawas Lapangan.

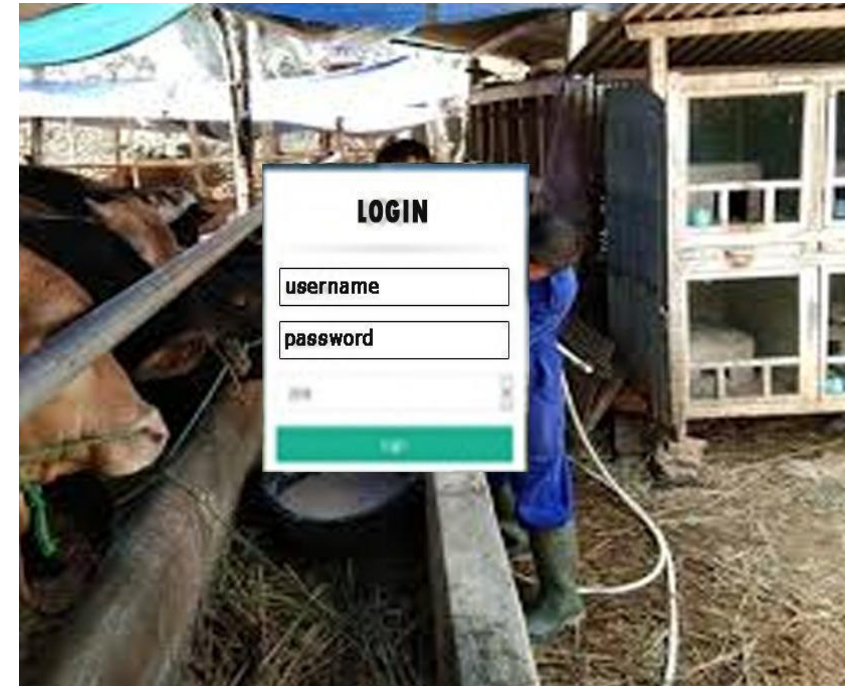

Gambar 8. Halaman Login Aplikasi Web 


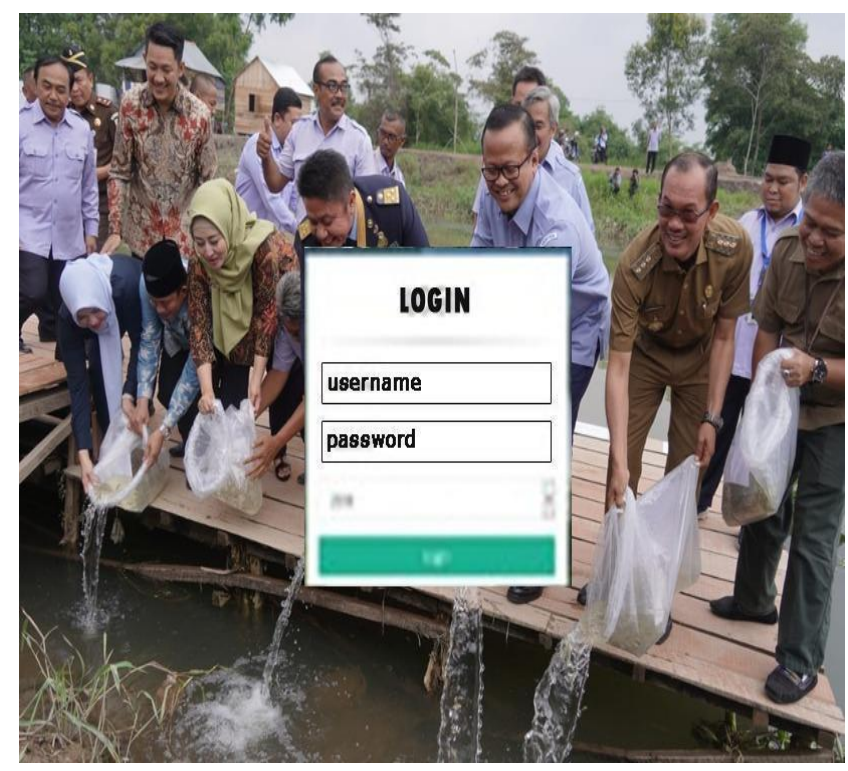

Gambar 9. Halaman Login Aplikasi Web

Dengan menampilkan data PL Pertanian dengan ID nya, bila di klik link tersebut akan memunculkan waktu login dan logout tiap waktunya di hari tertera.

\begin{tabular}{|c|c|c|c|c|c|}
\hline \multicolumn{6}{|c|}{ Data Absen Petugas Lapangan } \\
\hline \multicolumn{2}{|c|}{ Data Absen } & $\leq$ Back to Whatever Poge & & & \\
\hline \multicolumn{3}{|c|}{$\begin{array}{ll}\text { Persons (5) Ploces (4) Things (116) } \\
\end{array}$} & \multicolumn{3}{|c|}{$Q_{\text {search staff }}$} \\
\hline ID & Firstname & Last Activity & Jabatan & & \\
\hline 58011 & Abby & April 21,2011 at $9.12 P M$ ( 6 hours ago) & Supir Truck & Edit & 0 \\
\hline 58012 & Robet & April 21,2011 at 9:41PM (6 hours agos) & Supir Truck & Edit & 0 \\
\hline 58013 & Didi & April 21,2011 at 10:06PM (7 hours ago) & Supir Sweeper & Edit & 0 \\
\hline 58014 & Dana & (never signed-in) & Tukang Sapu & Edit & 0 \\
\hline 58016 & Edi & (never signed-in) & Supir Truck & Edit & 0 \\
\hline
\end{tabular}

Gambar 10. Data Absensi Petugas Lapangan Pertanian

Gambar 11 adalah posisi sebaran PL Pertanian yang dapat dilihat secara otomatis apabila PL Pertanian telah melaporkan aktivitasnya

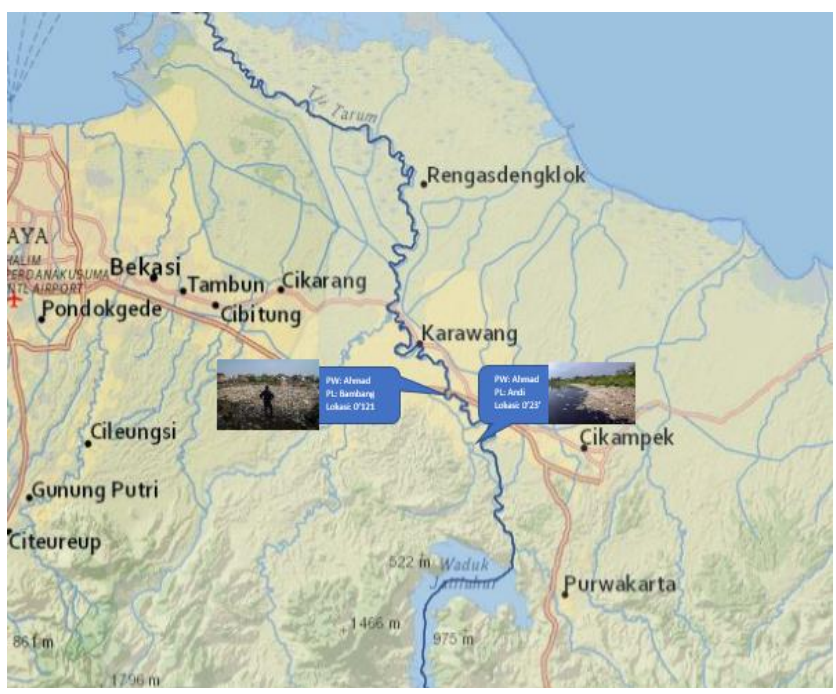

Gambar 11. Menu Sebaran Lokasi Petugas Lapangan

Tampilan menu di atas sebagai menu-menu aplikasi adalah kegiatan-kegiatan yang dilakukan dari PL Pertanian dengan menampilkan menu-menu sesuai kebutuhan, yaitu: (i) aktifitas, berfungsi untuk mengerjakan aktifitas rutin PL Pertanian dari Kasubbag Renlap yang dikirim secara rutin oleh sistem; (ii) aktivitas Lain, merupakan menu untuk mencatat dan melaporkan aktivitas lain selain kegiatankegiatan atau aktifitas rutin dari PL Pertanian; (iii) Fast Response, aktivitas ad-hoc dari Kasubbag Renlap yang perlu segera direspon oleh PL Pertanian setelah muncul tanda atau notifikasi sebagai pesan baru di handphone yang perlu segera ditindak lanjuti; (iv) History, adalah daftar kegiatan dari PL Pertanian, baik yang belum dikerjakan, sedang berjalan dan sudah selesai dari masing-masing aktivitas PL Pertanian tersebut. Sedangkan Gambar 12 adalah menu yang memfasilitasi penampilan PL Pertanian

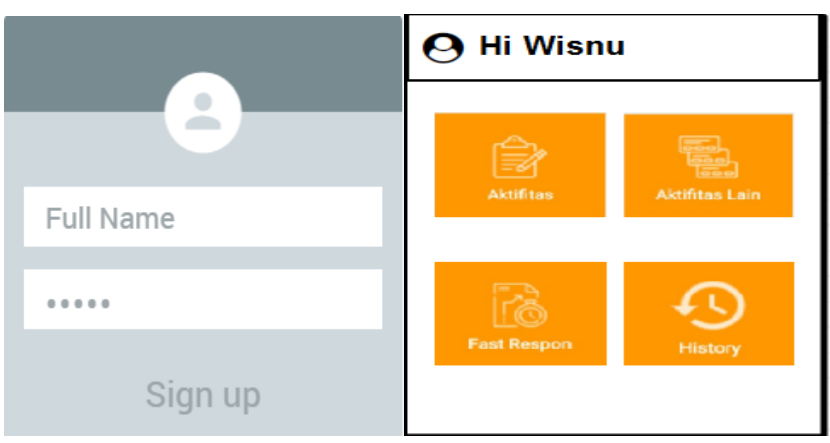

Gambar 12. Halaman Login dan halaman utama Aplikasi Android

\section{Hasil indeks keberlanjutan Sebaran Petugas Lapang dengan menggunakan loT}

Terdapat 13 (tiga belas) atribut yang disertakan dalam analisis keberlanjutan sebaran $\mathrm{PL}$ pertanian dalam melakukan kinerja sebagai Tim Pelaporan. Tiga belas atribut tersebut terdiri dari: (i) atribut ekologi (monev wilayah kekeringan dan banjir, mengurangi polusi, penghematan energi); (ii) atribut ekonomi (bertukar sumberdaya, memungkinkan bisa bertukar peralatan, mengurangi trade off antara komoditas pertanian dengan manajemen sistem agribisnis, lebih efisien dan efektif, Bertukar informasi); dan (iii) atribut sosial (mengurangi kesalahan manusia, melatih berkinerja secara sistemik, melatih berkinerja secara kolaborasi (Tim), peningkatan layanan Pelaku Agribisnis, memungkinkan melacak historis data, informasi).

Berdasarkan analisis yang dilakukan, nilai indeks keberlanjutan pendekatan revolusioner sebaran PL pertanian sebesar 87,57 persen, yang berarti bahwa kehadiran IOT sebagai pendekatan revolusioner untuk mendukung sebaran PL pertanian dalam berkinerja yang diteliti dinilai berkelanjutan (Gambar 13). 


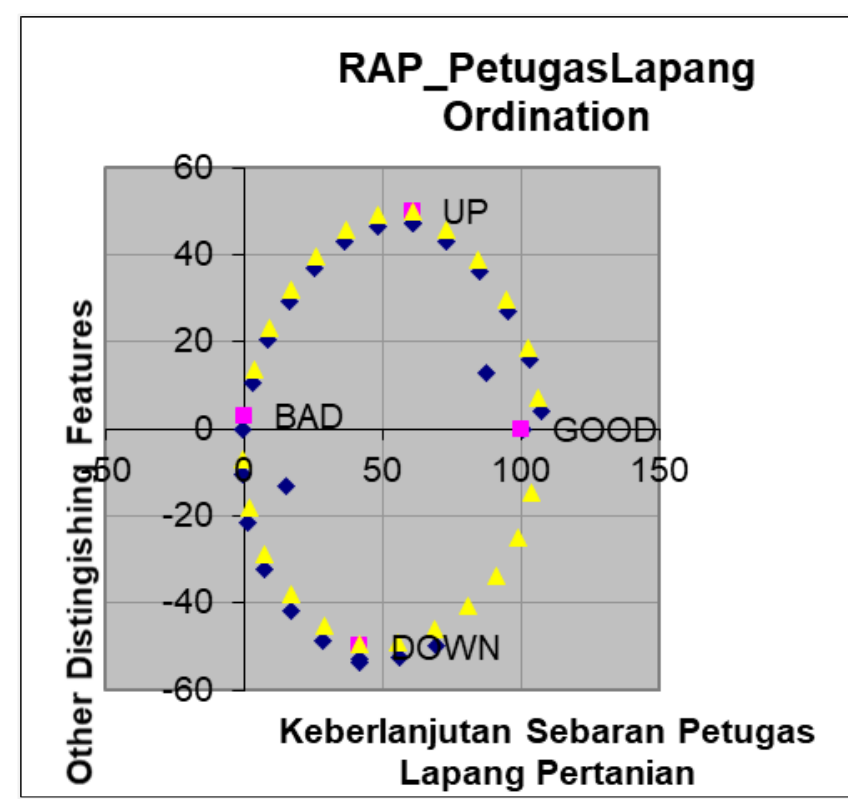

Gambar 13. Nilai Indeks Keberlanjutan

Dari tigabelas atribut-atribut yang disertakan dalam analisis keberlanjutan, atribut yang diperkirakan memberikan pengaruh besar adalah melatih berkinerja secara sistemik, dengan nilai Root Mean Square (RMS) tertinggi sebesar 5,11 (Gambar 14).

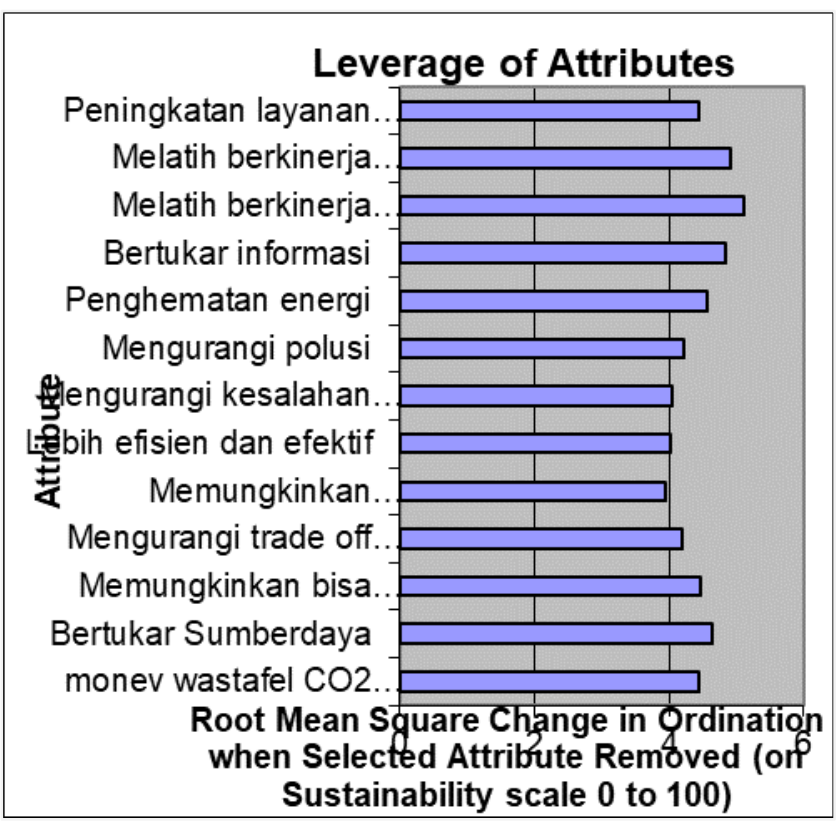

Gambar 14. Analisis Leverage

Sedangkan atribut leverage kedua adalah melatih berkinerja secara kolaborasi atau tim, dengan nilai RMS sebesar 4,92. Setelah dilakukan analisis aspek pengungkit atau leverage, kemudian dilakukan analisis Monte Carlo.

Perbedaan nilai hasil penghitungan MDS dengan hasil analisis Monte Carlo yang relatif kecil adalah 0,365 $(<1)$. Hal ini menunjukkan bahwa hasil penghitungan MDS dapat mencerminkan tingkat presisi yang tinggi. Validasi hasil simulasi Rap-PL menunjukkan bahwa daya penjelas atau koefisien determinasi $\left(R^{2}\right)$ memiliki nilai yang cukup tinggi adalah sebesar 0,9495 yang berarti bahwa ketiga belas atribut yang disertakan memiliki peran yang cukup besar dalam menjelaskan keragaman dari pendekatan revolusioner sebaran $\mathrm{PL}$ pertanian yang dibangun. Begitu juga besarnya nilai $S$ stress ialah 0,2077 atau lebih rendah dari 0,25 yang berarti ketepatan konfigurasi titik-titik (goodness of fit) model yang dibangun untuk keberlanjutan pendekatan revolusioner PL pertanian dapat merepresentasikan model yang baik.

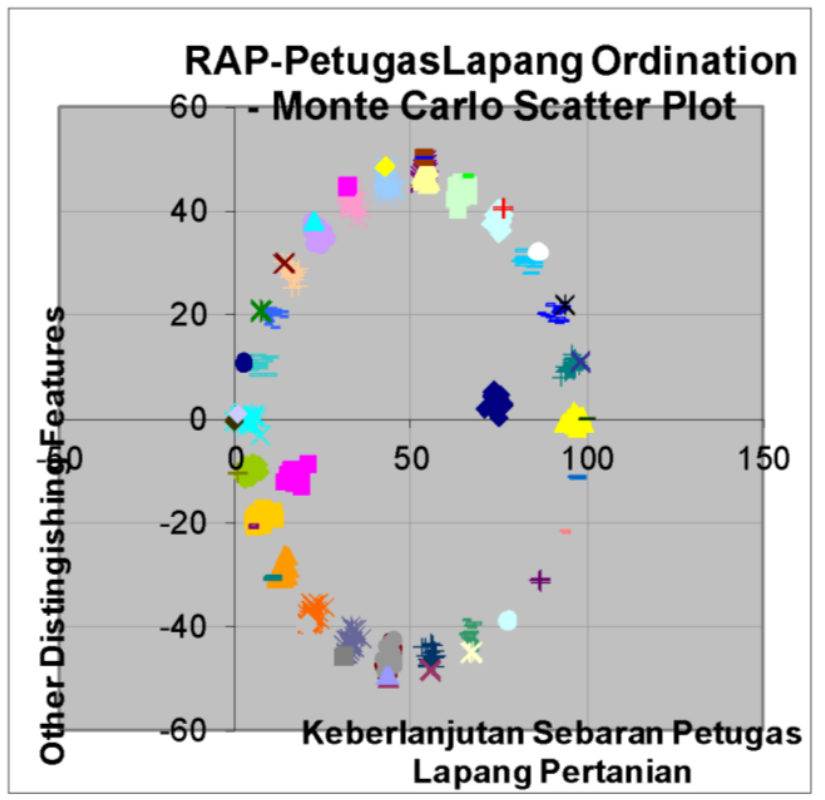

Gambar 15. Analisis Monte Carlo

\section{KESIMPULAN}

Aplikasi dibangun sesuai kebutuhan dari user dalam hal ini adalah PL Pertanian sesuai wilayah kerja dan binaannya. Ruang lingkup aplikasi website bagi Kasubbag Renlap sebagai pengawas lapangan, Kabag TU dan Kabid sebagai supervisor, Kepala Dinas sebagai Manajer, serta Admin atau Super User digunakan untuk melakukan monitoring pengumpulan data dan informasi, laporan, serta sebaran $\mathrm{PL}$ Pertanian agar memaksimalkan perannya melalui aplikasi Android. Manfaat lain adalah memudahkan pengawasan dan pembinaan secara berjenjang bagi Kasubbag Renlap, Kabag dan Kabid sebagai supervisor, dan Kadis sebagai manajer melakukan monitor pendataan.

Selain itu dapat digunakan sebagai penanda kehadiran dari peserta PL Pertanian setelah melakukan login, melakukan transaksi harian sebagai aktivitas dan geotag foto yang diambil dari handphone di dalam laporan aktivitas yaitu dengan membuat titik sebaran, sehingga dapat dimonitor oleh Kasubbag Renlap, Kabag dan Kabid sebagai supervisor, dan Kepala Dinas sebagai manajer.

Penggunaan aplikasi sebaran PL pertanian sebagai pendekatan revolusioner IoT dinilai berkelanjutan dengan indeks sebesar 87,57 persen. Kondisi tersebut dapat ditingkatkan keberlanjutannya, apabila Para PL menghayati berkinerja secara kolaborasi dan berfikir sistemik dalam menyelesaikan permasalahan di lapangan, sehingga fast respon dapat lebih berkualitas.

\section{SARAN}

Saran dari kegiatan ini, setelah aplikasi ini dapat digunakan, ada baiknya lanjut ke sosialisasi dan bimbingan teknis bagi pengguna lainnya. Setelah itu, perlu dikembangkan dari data sesuai dengan informasi kebutuhan user. 


\section{UCAPAN TERIMAKASIH}

Kami mengucapkan terimakasih kepada Bapak Setiaji, ST., M. Si sebagai Kepala Dinas Komunikasi dan Informasi Pemerintah Daerah Provinsi Jawa Barat yang berkenan berdiskusi tentang pelaksanaan program Jawa Barat Digital Service (JDS). Beliau juga mendukung penelitian kami untuk diujicobakan di lokasi kabupaten kota yang sudah memiliki infrastruktur JDS.

\section{DAFTAR PUSTAKA}

Arbi, Muhammad. (2017). Analysis of Field Extention Worker's Performance in the Program of Community Food Distribution Institution in Makarti Jaya District, Banyuasin Regency, South Sumatera. Jurnal Penyuluhan, 13(2): 125-132.

Bagus Eryawan, Ari Endang Jayati, dan Sri Heranurweni. (2019). Rancang Bangun Prototype Smart Home Dengan Konsep Internet of Things (IOT) Menggunakan Raspberry $\mathrm{Pl}$ Berbasis Web. eLEKTRIKAL. 11(2): 1-5

BINUS University, Faculty Economic and Communication. (2020). Memahami System Development Life Cycle. https://accounting.binus.ac.id/2020/05/19/memahami -system-development-life-cycle/

Balakrishna, G. \& Moparthi, Nageswara. (2019). Study Report on Using IoT Agriculture Farm Monitoring. Innovations in Computer Science and Engineering (pp.483-491)

Joao Pedro Dias, Hugo Sereno Ferreira. (2018). State of the Software Development Life-Cycle for the Internet-ofThing. ACM. 1-38.

Kementerian Pendayagunaan Aparatur Negara dan Reformasi Birokrasi, (2020). Peraturan Menteri Pendayagunaan Aparatur Negara dan Reformasi Birokrasi Nomor 35 Tahun 2020 Tentang Jabatan Fungsional Penyuluh Pertanian. Kementrian Pendayagunaan Aparatur Negara dan Reformasi Birokrasi Republik Indonesia.

Kementerian Pertanian. (2019). Peraturan Menteri Pertanian Republik Indonesia Nomor 35 Tahun 2019 Tentang Penyelenggaraan Uji Kompetensi Jabatan Fungsional Bidang Pertanian. Kementrian Pertanian Republik Indonesia.

Kementerian Kelautan dan Perikanan, (2015). Pentingnya Peran Petugas Penyuluh Lapangan Sebagai Enumerator Perikanan Budidaya Di Kecamatan. Kementrian Kelautan dan Perikanan.

Kementerian Pertanian. (2016). Kisi-kisi Materi Uji Kompetensi Paramedik Veteriner. Materi Teknis Paramedik Veteriner. Kementrian Pertanian Republik Indonesia.

Kementerian Pertanian. (2014). Keputusan Menteri Ketenagakerjaan Republik Indonesia Nomor 403 Tahun 2014 Tentang Penetapan Standar Kompetensi Kerja Nasional Indonesia Kategori Jasa Profesional, IImiah Dan Teknis Golongan Pokok Jasa Profesional, IImiah dan Teknis Lainnya Bidang Penyuluh Perikanan. Kementrian Kelautan dan Perikanan Republik Indonesia.

Mulyanto, Agus. (2009). Perancangan Sistem Informasi dan Aplikasinya. Penerbit Pustaka Belajar. Yogyakarta.

Suryanegara, Muhammad \& Arifin, Ajib \& Asvial, M. \& Ramli, Kalamullah \& Nashiruddin, Muhammad Imam \& Hayati, Nur. (2018). What are the Indonesian Concerns About the Internet of Things (IOT)? Portraying the Profile of the Prospective Market. IEEE Access. PP. 1-1. 10.1109/ACCESS.2018.2885375.
Pannee Suanpang and Pitchaya Jamjuntr. (2019). A Smart Farm Prototype with an Internet of Things (IoT) Case Study: Thailand. Journal of Advanced Agricultural Technologies. Vol. 6, No. 4, pp. 241-245

Sachin Kumar, Prayag Tiwari and Mikhail Zymbler. 2019. Internet of Things is a revolutionary approach for future technology enhancement: a review. J Big Data 6:111.

Prapitasari, L.P.A., Sumiari, N.K., Jayanti, N.K.D.A. (2016). Sistem Informasi Geografis Pasar Tradisional di Wilayah Denpasar menggunakan Framework YII. SISFOTENIKA, No.2 Vol. 6.

Republika.co.id. (2019). Indonesia

Kekurangahttps://republika.co.id/berita/ekonomi/pert anian/19/02/11/pmrk9g423-indonesia-kekurangan40-ribu-penyuluh-pertanian 